\title{
AN INVESTIGATION OF THE FORCE AND TORQUE AT PROFILE SHEET METAL ROLLING - INPUT DATA FOR THE PRODUCTION SYSTEM REENGINEERING
}

\author{
Milan Jurkovic, Zoran Jurkovic, Milenko Obad, Stipo Buljan, Edin Mustafic
}

Original scientific paper

The fundamental basis for implementation of reengineering is: experimental measurement of forces and torques on the rollers-tools production line for profile sheet metal forming. The paper presents the experiments of measuring forces and torques, modeling and simulation in the aim of redesigning the process of sheet metal forming, selecting of the optimal process of sheet metal forming for each forming module and totally for the production line and increasing productivity on production lines. In the experimental research forces and torques were measured on the rollers of forming modules for profile forming of sheets for different values of the input parameters of the process: material type $\sigma_{\mathrm{m}}$, sheet thickness $s$ and sheet width $b$. Based on the experimental results mathematical models were defined, which enabled the analysis and implementation of reengineering the production system.

Keywords: algorithm; experiment; force; model; profile rolling; reengineering; torque

Ispitivanje sile i momenta profilnog oblikovanja lima pomoću valjaka - ulazni podaci za reinženjering proizvodnog sustava

Izvorni znanstveni članak Osnovne su podloge za izvedbu reinženjeringa: eksperimentalno mjerenje sila i momenata na valjcima-alatima proizvodne linije za profilno oblikovanje lima. U radu su prikazani pokusi mjerenja sila i momenata, modeliranje i simulacija u cilju: redizajna procesa oblikovanja lima, izbora optimalnog procesa oblikovanja lima za svaki obradni modul i ukupno za proizvodnu liniju i povećanja produktivnosti proizvodne linije. Eksperimentalnim istraživanjima izmjerene su sile i momenti na valjcima obradnih modula za profilno oblikovanje tankih limova za različite vrijednosti ulaznih parametara procesa: vrsta materijala $\sigma_{\mathrm{m}}$, debljina lima $s$ i širina lima $b$. Na temelju dobivenih eksperimentalnih rezultata definirani su matematički modeli koji su omogućili analizu i provedbu reinženjeringa proizvodnog sustava.

Ključne riječi: algoritam; eksperiment; model; moment; profilirano valjanje; reinženjering; sila

\section{Introduction}

Modern industrial production is based on market demand, optimal technology and technological processes, installation of knowledge into products and processes, innovation with the aim of better, cheaper and faster production $[1,2,3,4]$. Therefore, the market is the input format for production planning, which sets requirements: quantity, complexity, diversity of products, quality, value and time of product delivery.

In the development of competitive and modern production the application of reengineering tools that simplify processes is unavoidable, as well as reducing the amount of work and shortening production cycles, improving production performance, improving the quality of processes and achieving market-recognized production.

Experimental research and modeling was carried out in order to analyse and redesign the process of the profiled sheet metal forming, increase the quality and choice of optimal process of sheet metal forming and increase the productivity of the production line.

Forming thin-walled profiles by rollers in comparison with other methods of creating a profile has technical and economic advantages in productivity of the process, its automation, quality and production possibilities profile of greater dimensions $[5 \div 10]$.

Therefore, automated flexible manufacturing line for profile sheet metal forming is used more and more each day (Fig. 1). Experimental research of profiling sheet by rollers is performed in different directions.

In the master thesis [11] was investigated the process of sheet metal forming that is used in the production of long elements with constant cross section. Gehring [12] investigated the stress-strain state in the process of profiling sheet metal with analysis of state in the zones of stress concentration and comparison of results of experiment and simulation etc. The production line has 20 forming modules (length 10,20 m and width 2,0 m) and the experimental research in actual production is based on them (Fig. 1).

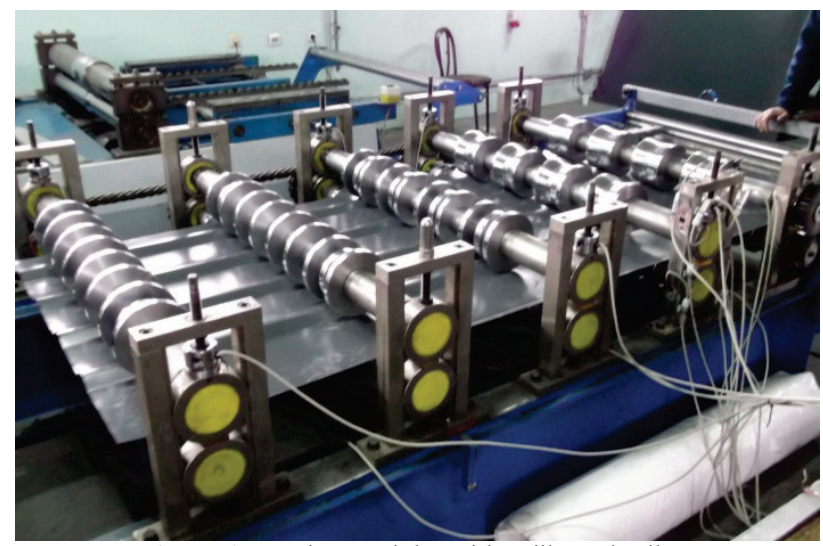

Figure 1 Forming modules with calibrated rollers

Each module has two calibrated rollers, upper and lower (Fig. 2) [13]. Driving power is $11 \mathrm{~kW}$ electric motor, the output is the speed of the gear $41 \mathrm{~min}^{-1}$, the transmission drives the rollers forming module is a chain, the maximum sheet width $1250 \mathrm{~mm}$, thickness of the sheet for forming from 0,4 to $1,0 \mathrm{~mm}$. The production system has a forming module for handling sheet metal, where the metal strip-sheet in coil mass $10000 \mathrm{~kg}$ and forming modules for profile sheet metal forming and cutting shears the profiled sheet at a certain length $[13,14]$. 


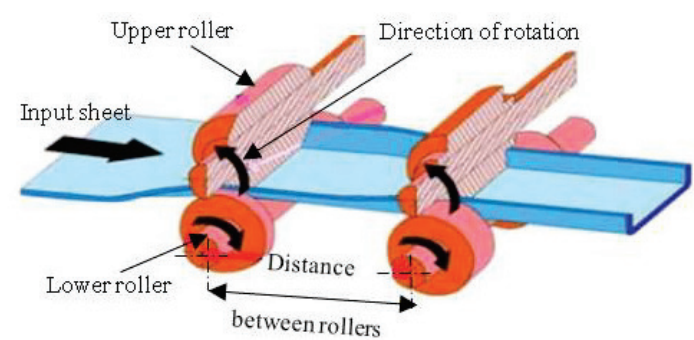

Figure 2 The profile sheet metal rolling process

\section{Experiment and experimental results}

\subsection{Experimental setup}

The experiment was realized in real production conditions in the production system for profiling forming sheets (Fig. 1). Production system is specially prepared with all the necessary resources for the implementation of the plan of the experiment.

\subsubsection{Materials}

For the experimental research material was selected according to the values of tensile strength $\sigma_{\mathrm{m}}$ : Steel sheet DX 51D (DIN 17162-1, EN 10327), mechanical properties: $\sigma_{\mathrm{m}}=383 \mathrm{~N} / \mathrm{mm}^{2} ; \sigma_{0,2}=278 \mathrm{~N} / \mathrm{mm}^{2}$, relative percentage extension after fracture material $\delta_{10}=31,3 \%$. Steel sheet DX 53D (DIN 17162-1, EN 10327), mechanical properties: $\sigma_{\mathrm{m}}=270 \mathrm{~N} / \mathrm{mm}^{2} ; \sigma_{0,2}=140$ $\mathrm{N} / \mathrm{mm}^{2}, \delta_{10}=30 \%$. Aluminium sheet Al 99,5 (EN 1050), mechanical properties: $\sigma_{\mathrm{m}}=130 \mathrm{~N} / \mathrm{mm}^{2} ; \delta_{10}=5 \%$.

Sample sheets for performance of experiment are: three types of sheet material $(130,270,383) \mathrm{N} / \mathrm{mm}^{2}$, three widths of the sample sheets $(950,1100,1250) \mathrm{mm}$ and three thicknesses $(0,50,0,60,0,70 \mathrm{~mm})$ and a length of $2500 \mathrm{~mm}$. Geometry of profiling sheet metal (Fig. 3) was obtained by continuous passage of the sheet between the rollers, through twenty of the forming modules. At each forming module, the bending is performed according to plan design and geometrical shape of calibration rollers.

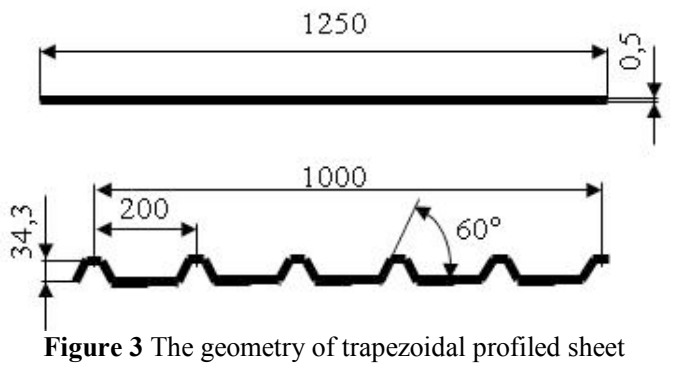

\subsubsection{Measuring equipment}

Measuring equipment used for this experiment is classified into two groups:

1) Measuring equipment for measuring roller force load:

- encoder with strain gauges, Fig. 1 and Fig. 4.

- multi-channel measuring amplifier HBM-QuantumX (MX840A), Fig. 6.

- multi-channel measuring amplifier HBM-SPIDER8 (8xSR55), Fig. 6.

- PC software for data acquisition, Fig. 6.

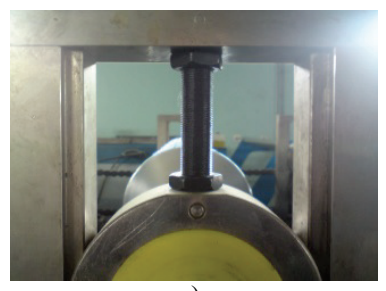

a)

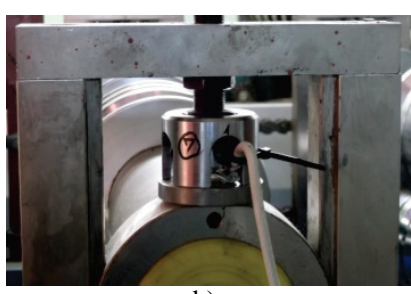

b)
Figure 4 Measuring location: a) without encoder, b) with set encoder

2) Measuring equipment for measuring torque on the drive spindle roller for profiling sheet metal $[10,13]$ :

- appropriate strain gauges 1-XY41-3/700 connect by bonding on the spindle roller in Fig. 5.

- telemetry, Fig. 7.

- multi-channel measuring amplifier HBM-QuantumX (MX840A), Fig. 7.

- $\quad$ PC software for data acquisition, Fig. 7.
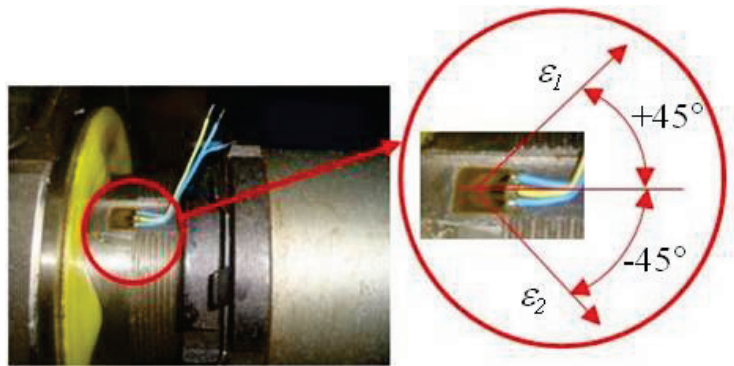

Figure 5 Strain gauge to measure torque on the drive spindle roller for profiling sheet metal

\subsection{Design of experiment and experimental results}

In Tab. 1 are presented experimental measured values of forces and torques on the spindle rollers during the profile sheet metal rolling, according to design of experiment $\left(N=2^{3}+4=12\right)$ and input process parameters.

Table 1 Design of experiment with measured values of force and torque

\begin{tabular}{|c|c|c|c|c|c|c|c|c|}
\hline \multirow[t]{3}{*}{$N$} & \multicolumn{3}{|c|}{$\begin{array}{l}\text { Input process } \\
\text { parameters }\end{array}$} & \multicolumn{3}{|c|}{$\begin{array}{c}\text { Coded } \\
\text { process } \\
\text { parameters }\end{array}$} & \multicolumn{2}{|c|}{$\begin{array}{l}\text { Measured values of } \\
\text { forces and torques }\end{array}$} \\
\hline & $\sigma_{\mathrm{m}}$ & $S$ & $b$ & $X_{1}$ & $X_{2}$ & $X_{3}$ & Force $F^{E}$ & Torque $T^{E}$ \\
\hline & $\mathrm{MPa}$ & $\mathrm{mm}$ & $\mathrm{mm}$ & - & - & - & $\mathrm{N}$ & $\mathrm{N} \cdot \mathrm{m}$ \\
\hline 1 & 130 & 0,5 & 950 & -1 & -1 & -1 & 223 & 24,30 \\
\hline 2 & 383 & 0,5 & 950 & 1 & -1 & -1 & 680 & 35,20 \\
\hline 3 & 130 & 0,7 & 950 & -1 & 1 & -1 & 535 & 40,75 \\
\hline 4 & 383 & 0,7 & 950 & 1 & 1 & -1 & 1194 & 53,15 \\
\hline 5 & 130 & 0,5 & 1250 & -1 & -1 & 1 & 230 & 26,36 \\
\hline 6 & 383 & 0,5 & 1250 & 1 & -1 & 1 & 1025 & 57,85 \\
\hline 7 & 130 & 0,7 & 1250 & -1 & 1 & 1 & 777 & 48,35 \\
\hline 8 & 383 & 0,7 & 1250 & 1 & 1 & 1 & 1950 & 69,60 \\
\hline 9 & 270 & 0,6 & 1100 & 0 & 0 & 0 & 814 & 36,35 \\
\hline 10 & 270 & 0,6 & 1100 & 0 & 0 & 0 & 735 & 35,76 \\
\hline 11 & 270 & 0,6 & 1100 & 0 & 0 & 0 & 750 & 39,27 \\
\hline 12 & 270 & 0,6 & 1100 & 0 & 0 & 0 & 820 & 33,90 \\
\hline
\end{tabular}

\section{Mathematical modelling}

\subsection{Selection and coding of the forming force parameters}

Force and torque of sheet metal profile rolling are defined by three variables of the process $[10,13,14]$ : the material type according to values of tensile strength $\sigma_{\mathrm{m}}$, the thickness of the sheet $s$ and width $b$, in Fig. 8 . 


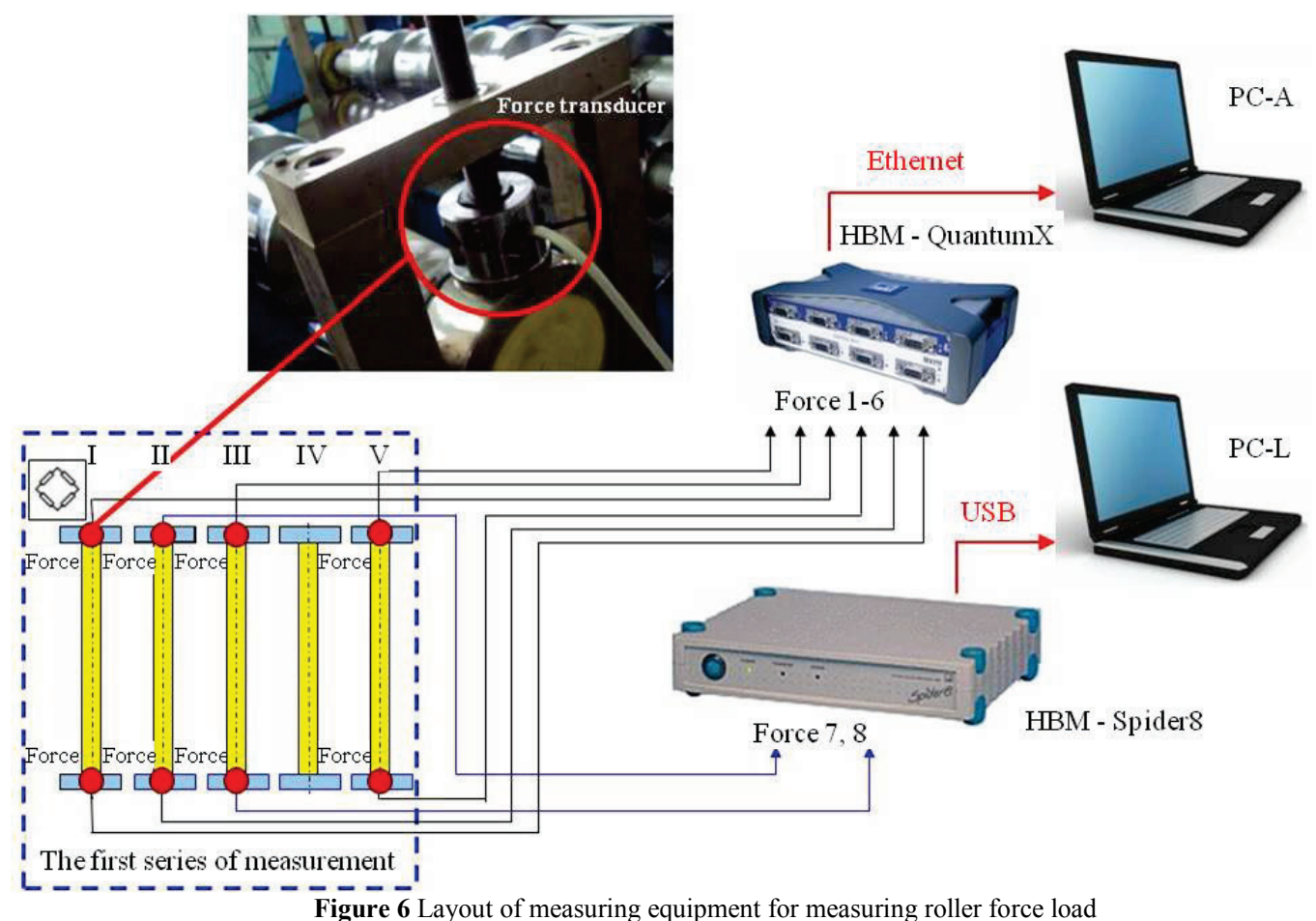

Figure $\mathbf{6}$ Layout of measuring equipment for measuring roller force load

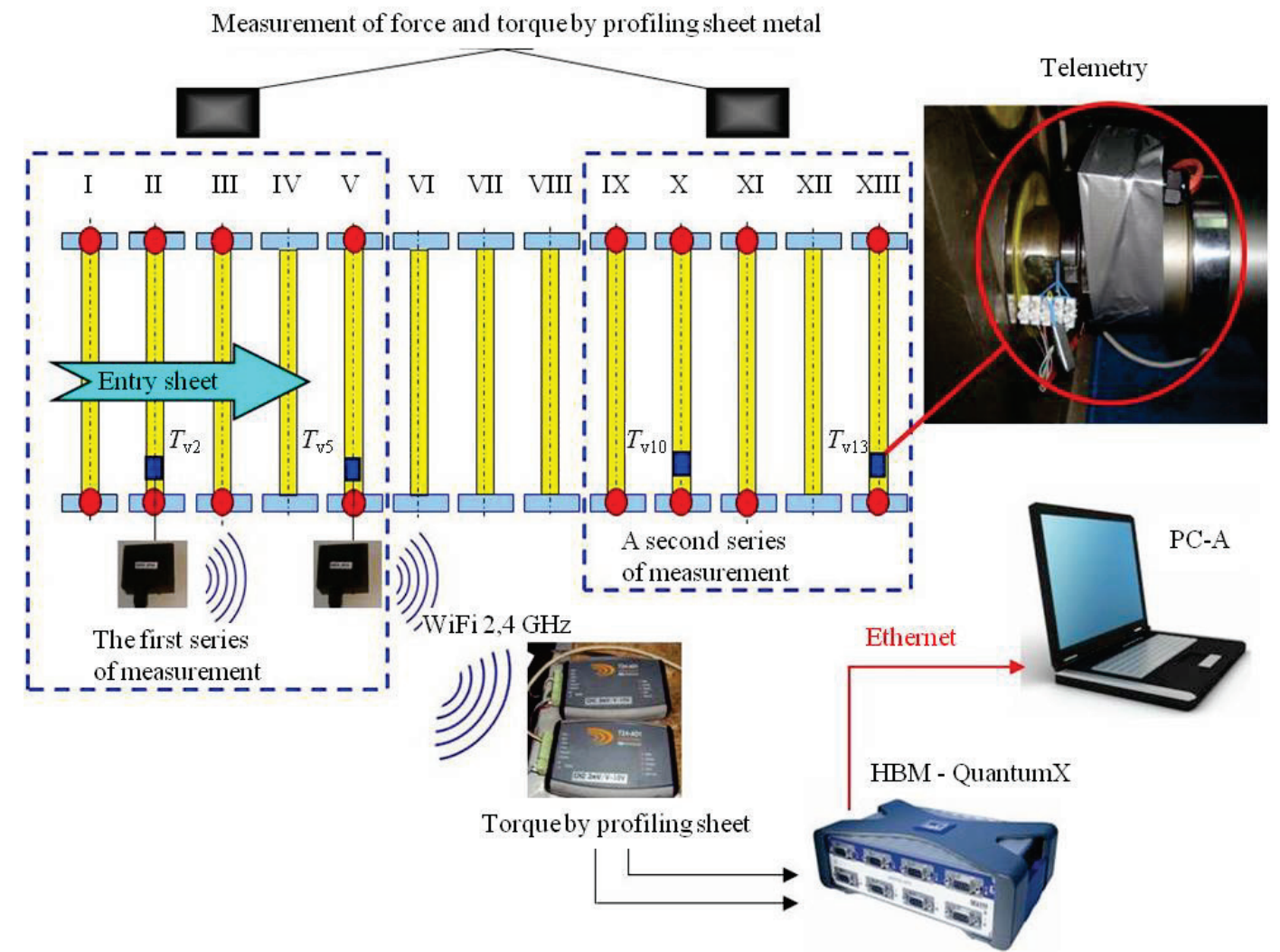

Figure 7 Layout of measuring equipment for measuring force and torque profiling sheet metal by rollers

Constant parameters of profiled sheet metal rolling are: foming system, geometry of calibration rollers, lubrication, chamfer radius of rollers, bending angle and stiffness of the rolls system (tools).

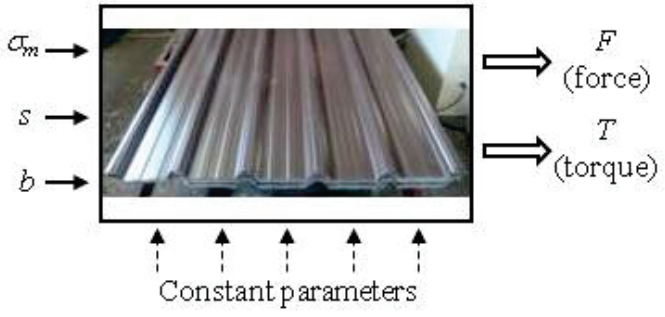

Figure 8 Block diagram of input and output parameters of the process of the profiled sheet metal forming 


\subsection{Mathematical modeling of the force profiling sheet metal by rollers}

Based on the experimental results by applying mathematical modeling a model in coded form was obtained (1) for force profiling sheet metal by rollers:

$y=6,54558+0,54706 \cdot X_{1}+0,41644 \cdot X_{2}+$

$+0,15941 \cdot X_{3}-0,10809 \cdot X_{1} \cdot X_{2}+0,05824 \cdot X_{1} \cdot X_{3}+$

$+0,04921 \cdot X_{2} \cdot X_{3}-0,03646 \cdot X_{1} \cdot X_{2} \cdot X_{3}$.

Decoding model (1) to obtain the mathematical model in physical form:

$y=\ln F=19,5009-5,118 \cdot \ln \sigma_{\mathrm{m}}-5,9926 \cdot \ln s-$

$-1,9676 \cdot \ln b-1,1894 \cdot \ln \sigma_{\mathrm{m}} \cdot \ln s+0,7853 \cdot \ln \sigma_{\mathrm{m}} \cdot \ln b+$

$+2,1306 \cdot \ln s \cdot \ln b$.

Model (2) adequately describes the dependence of the force of the sheet profiling process parameters $F=F\left(\sigma_{\mathrm{m}}\right.$, $s, b)$. Multiple regression coefficient is $R=0,98$, which confirms the adequacy of the obtained mathematical model.

\subsection{Mathematical modeling of the torque profiling sheet metal by rollers}

Modeling torque $T$ profiling sheet by rollers was done according to the procedure of modeling the torque on the spindle of the main electric motor. For the modeling of torque profiling sheet the same input process parameters were also used: $\sigma_{m}$ - tensile strength of the sheet metal, $s$-sheet thickness $s$ and $b$-width of the sheet.

Procedure of mathematical modeling and certain mathematical transformations obtained by the model (3) to calculate the torque needed to profile the sheet metal using rollers in the form of:

$$
T=\mathrm{e}^{30,281} \cdot \frac{s^{5,205} \cdot b^{0,862 \cdot \ln \sigma_{\mathrm{m}}}}{\sigma_{\mathrm{m}}^{(6+0,726 \cdot \ln s)} \cdot b^{3,732}} .
$$

\section{Analysis of results}

Fig. 9 shows the differences of load rollers in forming modules I, II, III and V measured in 12 experiments carried out. Force difference after profiling forming modules is more than $50 \%$ as a result of the planning of sheet metal process.

The value of the profiling metal sheet force in the second series of measurements for experiments: 9, 10, 11 and 12 is approximately equal for a certain forming module. This is because these four experiments are repeated at the same point of the experiment, i.e., they have the same values of input parameters of the profiling sheet metal process.

Similar differences force loading rollers, there are also differences of measured torque profiling sheet metal machining modules, II, V, X and XIII (Fig. 10).

Analysis of the results of the measured torque on spindles rollers for four modules: II, V, X and XIII show that there is the torque of sheet metal profiling, while the overall torque consists of: torque of sheet metal profiling, friction torque and torque of idling.

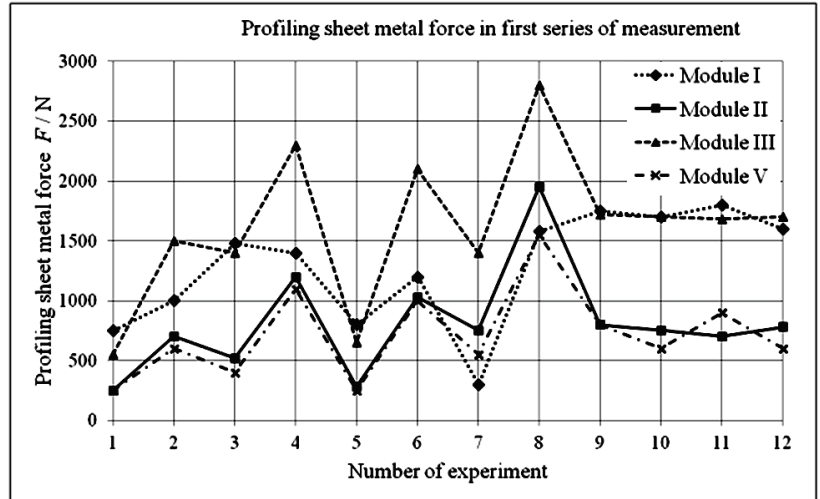

Figure 9 Profiling sheet metal force in the first series of measurements by the experiments and forming modules I, II, III and V

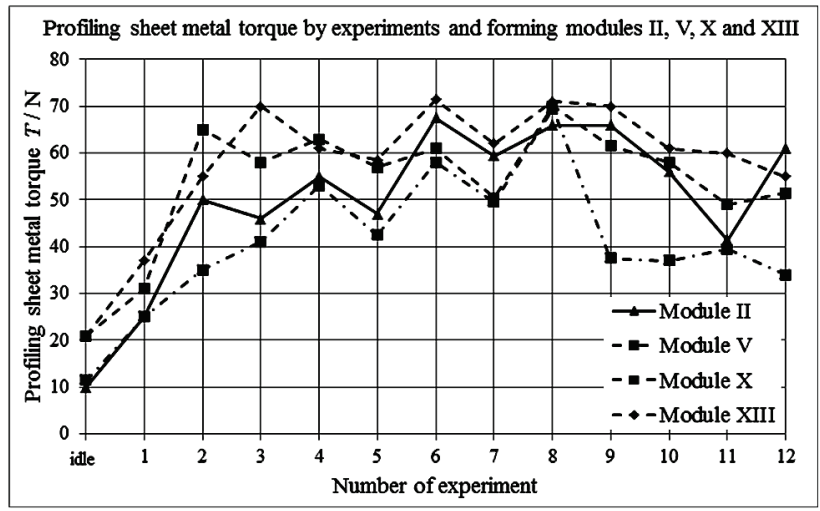

Figure 10 The measured torque of profiling sheet metal on drive spindles rollers by experiments from idle to 12 and forming modules: II, $\mathrm{V}, \mathrm{X}$ and $\mathrm{XIII}$

Experiments 9, 10,11 and 12 were performed in the zero point of the experimental plan where there were the same values of the input parameters of the process, but the different measured values of torques of sheet metal forming (large dispersion value of torque), except for the forming module $\mathrm{V}$, where the values are approximately equal (uniform) as expected.

Torques of profiling sheet metal on spindles rollers $X$ and XIII are higher than on spindles rollers II and V which depends on technological plan of sheet metal forming process.

\section{Reengineering the production line for profiled sheet metal rolling}

\subsection{The parameters of force, torque and reengineering}

Experimental research and modeling of processes and systems for sheet metal forming using rollers was performed because of the implementation of reengineering in order to achieve optimal value of technological, energy and economic parameters. The force and torque on the roller forming modules are mechanical size that depends on the same parameters of the forming process of sheet metal: tensile strength sheet metal $\sigma$, thickness $s$ and width of the sheet $b$. Thus, the force of the process of forming the profiled sheet metal: $F=f(\sigma, s, b)$, respectively the torque $T_{r}=f(\sigma, b, \varphi, s$, $\ldots)$, wherein the degree of deformation (bending sheet 
metal passages, $\varphi$ ). Modelling the obtained models of force (2) and torque (3 and 4) the function of the displayed parameters, why is derived experimentaly research. The parameters are reengineering technologicaltechnical, energy and economic. Technological parameters of the process that should have the optimum values are determined by minimization of forces forming sheet metal and respected economic criterium - minimum cost. Energy criterion based on minimum consumed energy, which has been in function: the optimal plan of sheet metal by forming modules, reducing the energy idle which requires optimal design drive and a transmission mechanism for transmitting power from the of driving electric motor to roller forming module.

Also, an important indicator of optimum process and optimum production system is the maximum degree of utilization of energy, ie: $\eta_{\mathrm{e}}=f\left(n, N, T_{\mathrm{r}}, T_{\mathrm{i}}, \ldots\right)$, where: $n$ number of revolutions of the spindle driving electric motor; $N$ - number of forming module; $T_{\mathrm{r}}-$ torque rolling, ie. torque deformation and resulting frictional force between the sheet metal and the rollers and $T_{\mathrm{i}}-$ torque idle.

\subsection{Achievements implementation of reengineering}

Reengineering involves redefining and redesigning existing processes or systems in order to achieve top results and competitive advantage in the market. To this end: Design optimal technological process of the profiled sheet metal to enable an equalizer load forming modules and to increase the effect of production on condition of increase of useful work of sheet metal profiling in the total energy consumed: $E_{\mathrm{k}} \rightarrow \max E_{\mathrm{k}}\left(E_{\mathrm{k}}-\right.$ useful energy). An optimal technological process has to supply: maximum possible technological parameters of the process, greater angle of bending sheet metal per forming module, profiles production with very thick sheet with respect to the installed power and the optimum feed rate production line depending on the complexity of the profile, the type of material and the quality of profile.

The technological process of forming sheet has been redesigned by increasing the technological parameters of the process:

- major bending deformations of sheet per each forming module,

- $\quad$ selection of the optimum sheet metal forming process for each forming module (optimal plan of profiling sheet) and

- increasing flow rate sheet production line.

Productivity of production line has to increase $30 \%$ by better capacity utilization of forming modules and equal load of each forming modules.

Technological, technical and energy compliance of the production system and profiling sheet metal process (adequacy of system and process).

\subsection{The reengineering algorithm of the production system}

Reengineering of the production system is the identification and analysis of the state of the production system, defining the problems that have implemented reengineering and determine the objectives of reengineering. Technical and economic analysis should show the validity of implementation of reengineering, as reengineering should not be a new cost but the solution of production and other problems, Fig. 11.

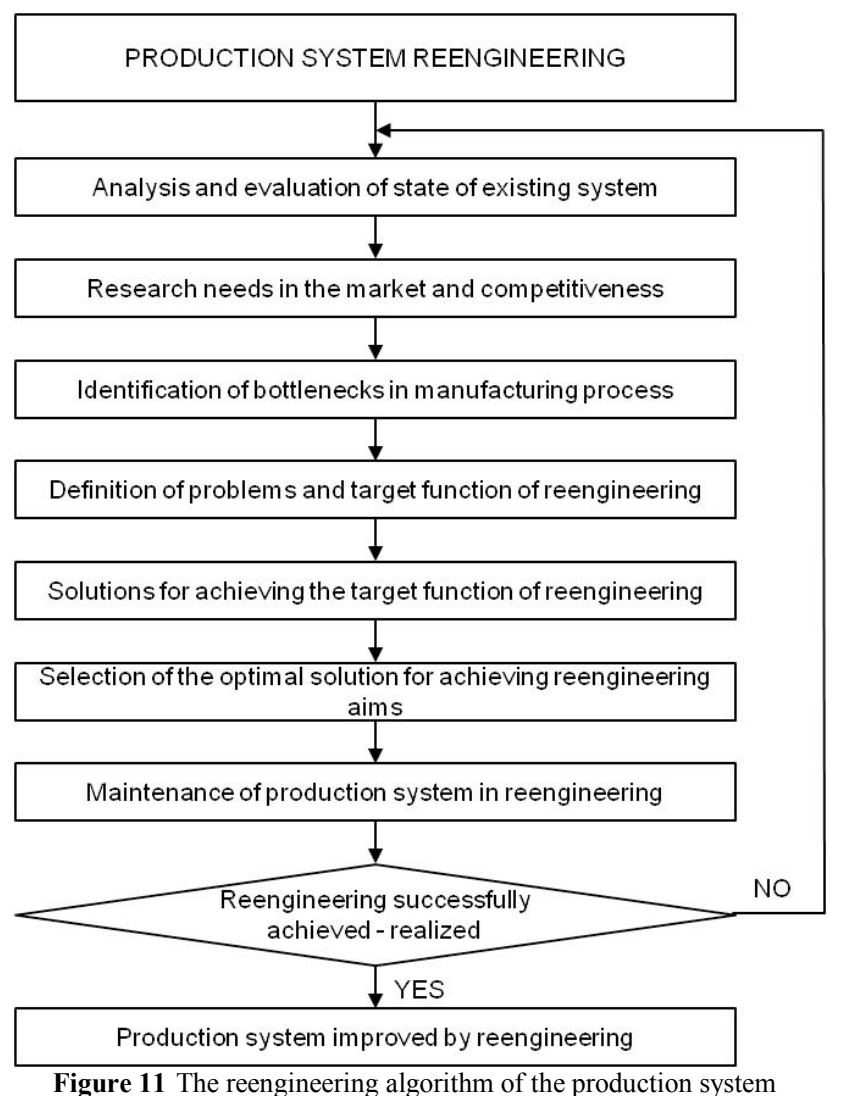

\section{Conclusions}

This realized experiment and modeling of force and torque of sheet metal process is conducted with the aim of implementing of reengineering of production line for profile sheet metal forming for the purpose of testing process and system, selecting optimal process sheet metal forming and increasing the productivity of the production line.

Realized reengineering of the production line for profile sheet metal forming by rollers achieved major goals:

- the technological process of the profiled sheet metal forming is optimized so that all forming modules are approximately equally utilized when the capacity of the production line has maximum efficiency.

- the technological process of sheet forming has been redesigned: the strain of bending metal sheet for each machining module is greater, defined with the optimal process of forming sheet and increased flow rate of profiled sheet metal production line.

- the productivity of the production line is increased by $30 \%$ as a result of higher capacity utilization of the forming modules, which is achieved by balanced load of forming modules. 


\section{Acknowledgements}

Research presented in this paper is realized in the framework of the project "Reengineering of manufacturing companies in order to gain competitive capabilities" supported by Federal Ministry of Education and Science of Bosnia and Herzegovina through grant No. $01-2440 / 13$ and also supported by University of Rijeka through grant OJ 212, MT 137.

\section{References}

[1] Jurković, M.; Jurković, Z.; Buljan, S.; Mahmić, M. Reinženjering proizvodnih poduzeća - razvoj i modernizacija proizvodnje. Tehnički fakultet, Univerzitet u Bihaću, Bihać, 2011.

[2] Hammer, M.; Champy, J. Reengineering the Corporation. Harper Business, A Division of Harper Collins Publishers, New York, 1993.

[3] Jurković, M. Matematičko modeliranje i optimizacija obradnih procesa. Tehnički fakultet Sveučilišta u Rijeci, Rijeka, 1999.

[4] Jurković, M. Matematičko modeliranje inženjerskih procesa i sistema. Tehnički fakultet, Univerzitet u Bihaću, Bihać, 1999.

[5] Jurkovic, M.; Jurkovic, Z.; Cukor, G.; Brezocnik, M.; Sekulic, M. Application of Modeling and Simulation in Reengineering of Manufacturing Processes. // Int. Research Expert Conference - Trends in the Development of Machinery and Associated Technology / Budapest, 2014, pp. 45-48.

[6] Bogojawlenskij, K. N.; Neubauer, A.; Ris, V. W. Technologie der Fertigung von Leichtbauprofilen. VEBDeutscher Verlag, Leipzig, 1979.

[7] Triševskij, I. S.; Doktorov, I. S. Teoretičeskie osnovy processa profilirovanija. Metallurgija, Moskva, 1980.

[8] Lange, K. Handbook of Metal Forming. Society of Manufacturing Engineers Dearborn, Michigan, 2006.

[9] Grizelj, B. Oblikovanje lima deformiranjem. Strojarski fakultet Sveučilišta u Osijeku, Slavonski Brod, 2009.

[10] Jurković, M.; Mustafić, E. Mathematical modeling of the torque driving electric motor production line to the profiling forming thin sheets. // Proceedings Int. Scientific Conference on Production Engineering / Budva, 2013, pp. 47-52.

[11] Güner, A. Assessment of roll-formed products including the cold forming effects. Middle East Technical University, Ankara, 2007.

[12] Gehring, A. Beurteilung der Eignung von metallischem Band und Blech zum Walzprofilieren. Universitätsverlag Karlsruhe, Karlsruhe, 2008.

[13] Mustafić, E. Analiza opterećenja pogonskog mehanizma linije za profilno oblikovanje tankih limova valjcima. Tehnički fakultet, Univerzitet u Bihaću, 2013.

[14] Hasanagić, N. Teoretsko i eksperimentalno istraživanje sile profilisanja lima pomoću valjaka, Tehnički fakultet, Univerzitet u Bihaću, Bihać, 2013.

\section{Authors' addresses}

Milan Jurkovic, D. Sc. emeritus professor

Technical Faculty, University of Bihac

I. Ljubijankića bb, BA-77000 Bihać, Bosnia and Herzegovina E-mail: mi.jurkovic@gmail.com

Zoran Jurkovic, D. Sc. assoc. professor

Faculty of Engineering, University of Rijeka

Vukovarska 58, HR-51000 Rijeka, Croatia

E-mail: zoran.jurkovic@riteh.hr

Milenko Obad, D. Sc. full professor

Faculty of Mechanical Engineering and Computing,

University of Mostar

Matice hrvatske bb, BA-88000 Mostar, Bosnia and Herzegovina

E-mail: milenko.obad@fsr.ba

Stipo Buljan, D. Sc. assist. professor

Federal Ministry of Energy, Mining and Industry

A. Šantića bb, BA-88000 Mostar, Bosnia and Herzegovina

E-mail: stipo.buljan@tel.net.ba

Edin Mustafic, M. Sc.

Technical Faculty, University of Bihac

I. Ljubijankića bb, BA-77000 Bihać, Bosnia and Herzegovina

E-mail: edo74@bih.net.ba 